\title{
Simultaneous Equations to Estimate Aboveground Biomass of Pinus caribaea var. hondurensis
}

\author{
Vinícius Morais Coutinho ${ }^{1}$, Carlos Roberto Sanquetta ${ }^{1}$, \\ Patrícia Anjos Bittencourt ${ }^{2}$, Samuel Alves Silva ${ }^{1}$, Karina Henkel Proceke ${ }^{3}$, \\ Willian Macedo Delarrmelina ${ }^{4}$, Julia Moreau ${ }^{4}$ \\ ${ }^{1}$ Universidade Federal do Paraná - UFPR, Curitiba/PR, Brasil \\ ${ }^{2}$ Universidade Estadual do Sudoeste da Bahia - UESB, Vitória da Conquista/BA, Brasil \\ ${ }^{3}$ Universidade Estadual do Centro-Oeste - UNICENTRO, Irati/PR, Brasil \\ ${ }^{4}$ Universidade Federal do Espirito Santo - UFES, Alegre/ES, Brasil
}

\begin{abstract}
This study aimed to develop equations to predict the biomass of trunks, branches, needles and total individual biomass for Pinus caribaea var. hondurensis. A simultaneous equation system was also adjusted. Twenty (20) trees from the experimental area of the State University of Southwest Bahia (UESB), Vitória da Conquista, Bahia, Brazil, were measured and weighed, while 15 traditional models were tested for dry biomass modeling. Of the models tested for total aboveground biomass, trunk biomass and pine needle/leaf biomass, models 9, 9 and 6, respectively obtained the most accurate adjustments. The models with the best performance for branch biomass were model 2 and logistics. The use of the adjustment method for simultaneous equations assured properties of additivity between biomass compartments and total biomass, preventing distortions between the sum of the individual equations for each compartment and the total equation.
\end{abstract}

Keywords: simultaneous adjustment, aboveground biomass, modeling. 


\section{INTRODUCTION}

Forests have received increasing attention given their potential to contribute to reducing greenhouse effects due to their capacity to store carbon via natural biomass production (Sanquetta et al., 2011). Thus, forests are important to establish global carbon equilibrium, since different types of forests store different amounts of carbon as a function of their stage of succession, age, management regime and species composition (Watzlawick, 2004).

A tree's biomass can be quantified using two methods: direct and indirect (Rezende, 2000). The direct method involves felling the tree to exactly determine its measurements. However, when a significant number of measurements have been obtained, indirect methods such as regression models can be used, in which mathematical models are developed which allow us to estimate individual biomass and per unit area. Several studies have been carried out using modeling to estimate Pinus spp. biomass. For Pinus caribaea, the study by Lima et al. (2016) stands out.

In most cases, modeling to estimate tree biomass is performed in order to independently adjust models, meaning that the estimation is performed for each tree compartment (trunk, bark, branches, needles/leaves, miscellaneous). However, the sum of the estimated biomasses according to these equations for each compartment may not produce the same result obtained using an equation for total tree biomass, resulting in inconsistent results. In order to prevent this problem, equations for biomass compartments and for total biomass must be estimated together through simultaneous estimation, considering the principle of additivity (Kozak, 1970).

According to Parresol (1999), the simultaneous estimation technique provides a system of equations with statistically correlated constraints, which in the case of biomass, implies assembling the equations for total estimation and for the compartments with restrictions on the parameters, thereby assuring the additivity (principle). The specific methods to ensure the additivity of regression functions are presented by Cunia (1979) and Jacobs \& Cunia (1980). Dong et al. (2014) successfully employed the NSUR process (Non-linear Seemingly Unrelated Regressions) to obtain biomass estimates for Pinus koraiensis Sieb. et Zucc compartments.

Therefore, the present study aimed to develop allometric equations to estimate the total dry aboveground biomass and the dry biomass of three tree compartments (trunk with bark, needles and branches) for the Pinus caribaea species. Moreover, the study also aimed to develop a simultaneous adjustment evaluation for integrated estimates of these biomasses in a compatible manner.

\section{MATERIAL AND METHODS}

\subsection{Characterization of the study area}

The data used in this study was obtained from a Pinus caribaea var. hondurensis stand located in the experimental area of the State University of the Southwest of Bahia (UESB), in Vitória da Conquista - BA, Brazil, at the geographic coordinates $14^{\circ} 53$ 'S and $40^{\circ} 48^{\prime}$ ' W.

The region is characterized by a humid subtropical climate (Cwb) according to the Köppen classification adapted to Brazil (Alvares et al., 2013), with maximum and minimum temperatures of $25.3^{\circ} \mathrm{C}$ and $16.1^{\circ} \mathrm{C}$, respectively. Average annual precipitation is $733.9 \mathrm{~mm}$ and the altitude is $928 \mathrm{~m}$. The soil of the region is classified as Dystrophic Yellow Latosol (Melo et al., 2013).

\subsection{Data collection}

Twenty (20) trees of the Pinus caribaea var. hondurensis species from a 10-year-old plantation with spacing of $3 \mathrm{~m} \times 3 \mathrm{~m}$ were selected and felled. The selection was made within the diametric range of 8.2 to $23.7 \mathrm{~cm}$, distributed into five $\mathrm{DBH}$ classes (diameter at breast height) with an amplitude of four centimeters in each class. Therefore, two trees per DBH class were felled. Class amplitude was based on the standard deviation mean of DBH with bark for the population. The number of sample trees used was defined based on studies from the related literature, which adopted a sample number between 10 and 40 trees (Soares et al., 2010; Azevedo et al., 2011; Pelissari et al., 2011). The selected trees were submitted to DBH measurement, and total tree height (TH) was measured after felling. Green biomass quantification was performed by the direct method, with each tree separated into 3 compartments 
for weighing: trunk with bark, needles and branches (dry and green branches).

Next, sample portions representative of the needle/ leaf and branch biomasses were selected to quantify dry biomass, using about 300 grams per compartment. For the trunk, 3 discs per tree were extracted for dry biomass determination (from the base, middle and upper portions of the tree). For these determinations, the samples were dried in a drying oven with air circulation at a temperature of $65{ }^{\circ} \mathrm{C}$ until reaching constant weight. The dried sample portions were weighed in an electronic $1 \mathrm{~g}$ precision scale and the dry biomass percentages of each compartment were calculated based on the ratio (Equation 1):

$\operatorname{DM}(\%)=\frac{(\mathrm{DW})}{(\mathrm{GW})} * 100$

$\mathrm{DM}=$ dry matter (\%);

$\mathrm{DW}=$ total dry weight of the compartment $(\mathrm{g})$;

$\mathrm{GW}=$ total green weight of the compartment (g).

After determining the moisture content of the samples, it was possible to relate this to the green biomass in the field, thus obtaining the estimated dry biomass for the compartments of each tree.

\subsection{Statistical analysis and adjustment of mathematical models}

A simple linear correlation matrix was designed with the DBH, TH and wood density $(\rho)$ information obtained for the 20 tree samples for subsequent construction of models to estimate total dry biomass and dry biomass for each tree compartment (trunk, needles/leaves and branches).

Fifteen (15) allometric models were tested, of which 9 were linear and 6 were non-linear (biological growth models), totaling 60 adjusted models (total dry biomass, trunk with bark, needles/leaves and branches) (Table 1). The selected non-linear models only considered one independent variable and were used to estimate biomass as a function of the most easily obtained variable $(\mathrm{DBH})$; these methods included: Weibull (1951), Logistic (Nelder, 1961), Gompertz (Laird, 1965), Schumacher (1939), Silva-Bailey (Silva, 1986) and Richards (1959).

To correct the logarithmic discrepancy of the linearized models, the adjustment statistics were recalculated by applying the Meyer Correction Factor (Equation 2).

Table 1. Tested models for estimating total dry biomass and the compartments of Pinus caribaea var. hondurensis in Vitoria da Conquista, Bahia, Brazil.

\begin{tabular}{|c|c|c|}
\hline \multicolumn{2}{|c|}{ Model Number } & Model \\
\hline \multirow{9}{*}{ Linear models } & {$[1]$} & $Y=\beta_{0}+\beta_{1} \cdot D B H+\varepsilon$ \\
\hline & [2] & $Y=\beta_{0}+\beta_{1} \cdot D B H+\beta_{2} . D B H^{2}+\varepsilon$ \\
\hline & [3] & $Y=\beta_{0}+\beta_{1} \cdot D B H+\beta_{2} . D B H^{2} . T H+\varepsilon$ \\
\hline & [4] & $Y=\beta_{0}+\beta_{1} \cdot D B H+\beta_{2} . D B H^{2}+\beta_{3} . D B H^{2} . T H+\varepsilon$ \\
\hline & [5] & $Y=\beta_{0}+\beta_{1} \cdot D B H^{2}+\beta_{2} \cdot D B H^{2} \cdot T H+\varepsilon$ \\
\hline & [6] & $Y=\beta_{0}+\beta_{1} . D B H+\beta_{2} . T H+\varepsilon$ \\
\hline & [7] & $\log Y=\beta_{0}+\beta_{1} \cdot \log (D B H)+\varepsilon$ \\
\hline & {$[8]$} & $\log Y=\beta_{0}+\beta_{1} \cdot \log (D B H)+\beta_{2} \cdot \log (T H)+\varepsilon$ \\
\hline & [9] & $\log Y=\beta_{0}+\beta_{1} \cdot \log (D B H)+\beta_{2} \cdot \log (T H)+\beta 3 \cdot \log (\rho)+\varepsilon$ \\
\hline \multirow{6}{*}{ Non-linear models } & [10] Weibull & $f(x)=\beta_{0} \cdot\left(1-e^{-\beta_{1} \cdot x^{\beta_{2}}}\right)+\varepsilon$ \\
\hline & [11] Logistic & $f(x)=\beta_{0} /\left(1+\beta_{2} \cdot e^{-\beta_{2} \cdot x}\right)+\varepsilon$ \\
\hline & [12] Gompertz & $f(x)=\beta_{0} \cdot e^{-\beta_{1} \cdot e^{-\beta_{2} \cdot x}}+\varepsilon$ \\
\hline & [13] Schumacher & $f(x)=\beta_{0} \cdot e^{\left.-\beta_{1} \cdot\left(\frac{1}{x}\right)\right)+\varepsilon}$ \\
\hline & [14] Silva-Bailey & $f(x)=\beta_{0} \cdot e^{\left(\beta_{1} \cdot\left(\beta_{2}^{x}\right)\right)}+\varepsilon$ \\
\hline & [15] Richards & $f(x)=\beta_{0} \cdot\left(1-e^{\beta_{1}{ }^{*} x}\right)^{\beta_{2}}+\varepsilon$ \\
\hline
\end{tabular}

Where: $\mathrm{Y}=$ Dry biomass of each compartment $(\mathrm{kg}) ; \mathrm{DBH}=$ diameter at breast height $(\mathrm{cm})$; $\mathrm{TH}=$ total height $(\mathrm{m})$; $\rho=$ density of wood $\left(\mathrm{g} . \mathrm{cm}^{-3}\right) ; \log =$ logarithm in base $10 ; \beta_{0}, \beta_{1}, \beta_{2}$ and $\beta_{3}=$ regression coefficients; $\mathrm{f}(\mathrm{x})=$ total dry biomass or dry biomass of the compartments $(\mathrm{kg}) ; \mathrm{e}=$ exponential; $\mathrm{x}=\mathrm{DBH}(\mathrm{cm}) ; \varepsilon=$ random error. 


$$
\mathrm{FCM}=10^{0,5 *\left(\mathrm{~S}_{y x}^{2}\right)}
$$

Where:

$\mathrm{S}_{\mathrm{yx}}=$ Standard error of estimate.

Four different performance evaluation criteria were used to evaluate the models: Schlaegel determination coefficient $\left(\mathrm{R}_{\text {adj }}^{2}\right)$, standard error of the percentage estimate (Syx\%), Akaike Information Criterion (AIC) and graphical residual analysis. The graphical residual analysis was applied to visualize the deviations between the real and estimated values, and to identify any tendencies in the residual distribution of the equation. Homogeneity of variance, and normality and independence of residues were determined through the Breush-Pagan, Shapiro-Wilk and Durbin-Watson tests, respectively, all at $5 \%$ probability.

Moreover, the simultaneous estimation was developed by a system of equations, which made it possible to reconcile the estimates, meaning that the sum result of the equations from each compartment is similar to that of the equation for total individual dry biomass, ensuring the biomass additivity of tree components (Parresol, 1999).

Performance of the simultaneous adjustment followed the procedures described by Sanquetta et al. (2015) for biomass estimation. Therefore, the best performance model for each biomass compartment was selected, selecting models of the same nature (in the case of this study, only linear models). Next, the selected models were adjusted at the same time, establishing restrictions for the parameters in order to ensure that the equation for total biomass corresponded to the sum of the equations for each component $i$. The calculation was performed using iterative convergence to minimize the sum of squares of the residues using the Gauss-Newton method (Parresol, 2001). Each regression was adjusted using the biomass determined in the independent adjustment (Formulas 3, 4, 5 and 6). Thus, the procedure was applied using the PROC MODEL option of SAS, according to the following specifications:

$$
\begin{aligned}
& Y_{\text {trunk }}=f_{1}\left(X_{1 j}, \beta_{1 j}\right)+e_{1} \\
& Y_{\text {needles }}=f_{2}\left(X_{2 j}, \beta_{2 j}\right)+e_{2} \\
& Y_{\text {branches }}=f_{3}\left(X_{3 j}, \beta_{3 j}\right)+e_{3} \\
& Y_{\text {total }}=f_{\text {total }}\left(X_{1 j}, X_{2 j}, X_{3 j}, \beta_{1}, \beta_{2}, \beta_{3}\right)+e_{\text {total }}
\end{aligned}
$$

In which:

$\mathrm{Y}=$ Biomass of each tree compartment $(\mathrm{kg})$;

$\mathrm{f}=$ as a function of

See;

$\mathrm{X}=$ variables;

$\beta_{\mathrm{n}}=$ parameters.

Analysis of the performance of simultaneous adjustments was realized using the same statistical criteria employed to evaluate the independent models.

\section{RESULTS AND DISCUSSION}

Evaluating the descriptive statistics of the dependent and independent variables, an average diameter of $16.48 \mathrm{~cm}$ was observed for Pinus caribaea individuals, with a minimum value of $8.20 \mathrm{~cm}$ and a maximum of $23.70 \mathrm{~cm}$; average total height of $11.06 \mathrm{~m}$, ranging from $6.40 \mathrm{~m}$ to $14.20 \mathrm{~m}$; and mean density of $0.44 \mathrm{~g} . \mathrm{cm}^{-3}$ with a standard deviation of $0.15 \mathrm{~g} \mathrm{~cm}^{-3}$ (Table 2).

The average total individual dry biomass was $50.31 \mathrm{~kg}$. The trunk presented the largest participation in the individual compartment total biomass $(39.18 \mathrm{~kg}$ ), representing on average $77.88 \%$ of the total aboveground biomass, followed by branch biomass $(7.70 \mathrm{~kg})$ with $15.3 \%$ and needle biomass $(3.43 \mathrm{~kg}$ ) with $6.82 \%$. Similar relative values of aboveground biomass were found by Giongo et al. (2011) for 23-year-old Pinus elliottii plantations, located in the municipality of Rio Branco do Sul (PR, Brazil), in which the proportion of trunk biomass represented $81 \%$ of total biomass. In analyzing carbon stock in Pinus spp plantations in

\begin{tabular}{|c|c|c|c|}
\hline \multirow{2}{*}{ Variable } & \multirow{2}{*}{ Mean } & Standard & \multirow[t]{2}{*}{$\mathbf{N}$} \\
\hline & & Deviation & \\
\hline $\mathrm{DBH}(\mathrm{cm})$ & 16.48 & 3.64 & 20 \\
\hline $\mathrm{TH}(\mathrm{m})$ & 11.06 & 1.90 & 20 \\
\hline$\rho\left(\mathrm{g} \cdot \mathrm{cm}^{-3}\right)$ & 0.44 & 0.15 & 20 \\
\hline Trunk Biomass (kg) & 39.18 & 20.96 & 20 \\
\hline Needle/Leaf Biomass (kg) & 3.43 & 2.01 & 20 \\
\hline Branch Biomass (kg) & 7.70 & 4.28 & 20 \\
\hline Total Biomass (kg) & 50.31 & 26.42 & 20 \\
\hline
\end{tabular}
the State of Paraná, Balbinot et al. (2007) also found

Table 2. Descriptive statistics of dependent and independent variables used when adjusting models for biomass estimation. 
that the trunk compartment represented the highest percentage of biomass, with an upward trend as the tree grew.

\subsection{Correlation analysis between the variables involved}

Using simple linear correlation analysis it was possible to observe that the total aboveground biomass and the trunk, needle and branch compartment biomasses were more strongly correlated with $\mathrm{DBH}$ than with total height (TH) (Table 3$)$. The high correlation observed between $\mathrm{TH}$ and $\mathrm{DBH}$ variables (Table 4) indicates similarity in these variables for explaining biomass variation. When analyzing Pinus taeda and Pinus elliottii, Schikowski et al. (2013) also found high correlation values between $\mathrm{DBH}$ and total height $(r=0.97)$. On the other hand, density had a low correlation with the total and component biomasses when compared to other independent variables such as $\mathrm{DBH}$ and total height.

Table 3. Correlations between the biometric variables used in the settings.

\begin{tabular}{|c|c|c|c|c|c|c|c|}
\hline & DBH (cm) & TH (m) & $\rho\left(\right.$ g.cm $\left.^{-3}\right)$ & $\begin{array}{c}\text { Needle } \\
\text { Biomass } \\
\text { (kg) }\end{array}$ & $\begin{array}{c}\text { Branch } \\
\text { Biomass } \\
\text { (kg) }\end{array}$ & $\begin{array}{c}\text { Trunk } \\
\text { Biomass } \\
\text { (kg) }\end{array}$ & $\begin{array}{c}\text { Total } \\
\text { Biomass } \\
(\mathrm{kg})\end{array}$ \\
\hline $\mathrm{DBH}(\mathrm{cm})$ & 1 & & & & & & \\
\hline $\mathrm{TH}(\mathrm{m})$ & 0.813 & 1 & & & & & \\
\hline$\rho\left(\mathrm{g} \cdot \mathrm{cm}^{-3}\right)$ & 0.173 & 0.018 & 1 & & & & \\
\hline Needle Biomass (kg) & 0.734 & 0.712 & 0.355 & 1 & & & \\
\hline Branch Biomass (kg) & 0.797 & 0.618 & 0.573 & 0.726 & 1 & & \\
\hline Trunk Biomass (kg) & 0.877 & 0.723 & 0.500 & 0.851 & 0.849 & 1 & \\
\hline Total Biomass (kg) & 0.881 & 0.728 & 0.516 & 0.868 & 0.891 & 0.995 & 1 \\
\hline
\end{tabular}

Table 4. Adjusted models for biomass in different Pinus caribaea compartments.

\begin{tabular}{|c|c|c|c|c|c|c|c|c|c|}
\hline $\begin{array}{c}\text { Compart- } \\
\text { ment }\end{array}$ & Models & $\beta_{0}$ & $\beta_{1}$ & $\boldsymbol{\beta}_{2}$ & $\boldsymbol{\beta}_{3}$ & $\mathbf{R}_{\text {adjusted }}^{2}$ & $S_{y x}$ & $S_{y x} \%$ & AIC \\
\hline \multirow{15}{*}{ Needles } & 1 & -1.590150 & 0.196665 & & & 0.52 & 0.67 & 40.51 & -14.22 \\
\hline & 2 & -1.948940 & 0.244898 & -0.001535 & & 0.50 & 0.69 & 41.65 & -12.26 \\
\hline & 3 & -0.913616 & 0.123530 & 0.000160 & & 0.50 & 0.68 & 41.29 & -12.61 \\
\hline & 4 & -2.764560 & 0.411565 & -0.014287 & 0.000511 & 0.50 & 0.68 & 41.28 & -11.83 \\
\hline & 5 & 0.143643 & 0.002459 & 0.000244 & & 0.48 & 0.69 & 42.10 & -11.82 \\
\hline & 6 & -2.275050 & 0.124748 & 0.169092 & & 0.54 & 0.66 & 39.92 & -2.95 \\
\hline & 7 & -3.610890 & 3.075550 & & & 0.34 & 0.78 & 47.57 & -7.79 \\
\hline & 8 & -4.346510 & 1.553010 & 2.478750 & & 0.21 & 0.86 & 52.10 & -3.30 \\
\hline & 9 & -4.144330 & 1.153360 & 2.895130 & 0.402694 & 0.33 & 0.79 & 47.91 & -5.87 \\
\hline & Weibull & 14.249000 & 0.008268 & 0.981603 & & 0.33 & 0.79 & 47.94 & -6.63 \\
\hline & Logistc & 3.001940 & 229.280000 & 0.342447 & & 0.51 & 0.68 & 41.15 & -12.74 \\
\hline & Gompertz & 3.557660 & 14.485300 & 0.179183 & & 0.50 & 0.68 & 41.31 & -12.58 \\
\hline & Schumacher & 12.790900 & 33.839500 & & & 0.52 & 0.67 & 40.46 & -14.27 \\
\hline & Silva-Bailey & 0.000471 & 6.685170 & 1.011990 & & 0.42 & 0.74 & 44.78 & -9.35 \\
\hline & Richards & 1230.970000 & 0.002059 & 0.041189 & & 0.35 & 0.78 & 47.15 & -7.3 \\
\hline \multirow{9}{*}{ Branches } & 1 & -3.889810 & 0.470515 & & & 0.62 & 1.32 & 34.24 & 13.07 \\
\hline & 2 & -8.138820 & 1.041710 & -0.018173 & & 0.62 & 1.32 & 34.12 & 13.00 \\
\hline & 3 & -6.100170 & 0.709462 & -0.000522 & & 0.62 & 1.32 & 34.31 & 14.00 \\
\hline & 4 & -7.830960 & 0.978800 & -0.013359 & -0.000193 & 0.60 & 1.36 & 35.12 & 15.73 \\
\hline & 5 & -0.914562 & 0.026467 & -0.000828 & & 0.57 & 1.41 & 36.55 & 16.53 \\
\hline & 6 & -3.478740 & 0.513679 & -0.101489 & & 0.60 & 1.36 & 35.10 & 14.92 \\
\hline & 7 & -4.087750 & 3.770120 & & & $<0.1$ & 2.24 & 57.93 & 34.10 \\
\hline & 8 & -4.070990 & 3.804810 & -0.056476 & & $<0.1$ & 2.31 & 59.69 & 36.16 \\
\hline & 9 & -3.664760 & 3.001840 & 0.780123 & 0.809088 & 0.49 & 1.53 & 39.64 & 20.57 \\
\hline
\end{tabular}


Table 4. Continued...

\begin{tabular}{|c|c|c|c|c|c|c|c|c|c|}
\hline $\begin{array}{l}\text { Compart- } \\
\text { ment }\end{array}$ & Models & $\beta_{0}$ & $\beta_{1}$ & $\boldsymbol{\beta}_{2}$ & $\boldsymbol{\beta}_{3}$ & $\mathbf{R}_{\text {adjusted }}^{2}$ & $S_{y x}$ & $S_{y x} \%$ & AIC \\
\hline \multirow{6}{*}{ Branches } & Weibull & 24.540500 & 0.013693 & 0.921127 & & 0.37 & 1.70 & 43.90 & 23.87 \\
\hline & Logistc & 5.606350 & 9764.160000 & 0.630520 & & 0.67 & 1.24 & 32.06 & 11.29 \\
\hline & Gompertz & 6.081330 & 111.365000 & 0.347799 & & 0.66 & 1.25 & 32.38 & 11.69 \\
\hline & Schumacher & 27.271000 & 32.069500 & & & 0.62 & 1.33 & 34.32 & 13.16 \\
\hline & Silva-Bailey & 0.015851 & 4.175830 & 1.016570 & & 0.45 & 1.59 & 41.17 & 21.30 \\
\hline & Richards & 289.876000 & 0.006522 & 0.130443 & & 0.42 & 1.63 & 42.15 & 22.24 \\
\hline \multirow{15}{*}{ Trunk } & 1 & -23.174300 & 2.627070 & & & 0.76 & 5.38 & 21.00 & 69.20 \\
\hline & 2 & -22.386500 & 2.521170 & 0.003369 & & 0.74 & 5.54 & 27.53 & 71.20 \\
\hline & 3 & -21.124700 & 2.405510 & 0.000484 & & 0.74 & 5.53 & 27.50 & 71.15 \\
\hline & 4 & -24.042300 & 2.859530 & -0.022520 & 0.001038 & 0.73 & 5.69 & 28.31 & 73.10 \\
\hline & 5 & -3.836320 & 0.093832 & -0.000818 & & 0.72 & 5.72 & 28.45 & 72.51 \\
\hline & 6 & -24.130300 & 2.526690 & 0.236025 & & 0.74 & 5.53 & 27.50 & 71.15 \\
\hline & 7 & -2.479460 & 3.058660 & & & 0.60 & 6.86 & 34.12 & 78.92 \\
\hline & 8 & -2.455810 & 3.107610 & -0.079690 & & 0.58 & 7.07 & 35.15 & 89.96 \\
\hline & 9 & -2.097130 & 2.398640 & 0.658970 & 0.714370 & 0.91 & 3.27 & 16.24 & 50.88 \\
\hline & Weibull & 44.320700 & 0.000059 & 3.291160 & & 0.75 & 5.40 & 26.88 & 70.24 \\
\hline & Logistc & 37.743500 & 503.069000 & 0.384253 & & 0.77 & 5.25 & 26.11 & 69.08 \\
\hline & Gompertz & 44.278100 & 22.501300 & 0.203564 & & 0.76 & 5.30 & 26.37 & 69.48 \\
\hline & Schumacher & 200.267000 & 38.189200 & & & 0.76 & 5.33 & 26.51 & 68.83 \\
\hline & Silva-Bailey & 0.003229 & 7.312350 & 1.010560 & & 0.61 & 6.78 & 33.72 & 79.31 \\
\hline & Richards & 1114.300000 & 0.007622 & 0.152434 & & 0.50 & 7.69 & 38.23 & 84.33 \\
\hline \multirow{15}{*}{ Total } & 1 & -28.654200 & 3.294250 & & & 0.77 & 6.57 & 25.66 & 77.22 \\
\hline & 2 & -32.474000 & 3.807750 & -0.016337 & & 0.75 & 6.76 & 26.38 & 79.18 \\
\hline & 3 & -28.138400 & 3.238490 & 0.000122 & & 0.75 & 6.76 & 26.40 & 79.22 \\
\hline & 4 & -34.637600 & 4.249870 & -0.050165 & 0.001356 & 0.74 & 6.95 & 27.12 & 81.07 \\
\hline & 5 & -4.607220 & 0.122758 & -0.001402 & & 0.73 & 7.09 & 27.69 & 81.12 \\
\hline & 6 & -29.884100 & 3.165110 & 0.303637 & & 0.94 & 6.76 & 26.37 & 81.12 \\
\hline & 7 & -2.449460 & 3.120210 & & & 0.56 & 9.04 & 35.29 & 89.96 \\
\hline & 8 & -2.453570 & 3.111700 & 0.013862 & & 0.53 & 9.31 & 36.35 & 92.00 \\
\hline & 9 & -2.093310 & 2.399600 & 0.755784 & 0.717524 & 0.91 & 4.17 & 16.29 & 60.67 \\
\hline & Weibull & 52.996800 & 0.000056 & 3.341420 & & 0.77 & 6.59 & 25.72 & 78.17 \\
\hline & Logistc & 45.936500 & 576.539000 & 0.400757 & & 0.78 & 6.39 & 24.92 & 76.91 \\
\hline & Gompertz & 52.869900 & 25.695400 & 0.217948 & & 0.78 & 6.44 & 25.15 & 77.27 \\
\hline & Schumacher & 237.114000 & 36.883600 & & & 0.77 & 6.55 & 25.55 & 77.05 \\
\hline & Silva-Bailey & 0.007198 & 7.831580 & 1.002840 & & 0.17 & 12.41 & 48.44 & 103.49 \\
\hline & Richards & 1319.590000 & 0.007903 & 0.158058 & & 0.52 & 9.45 & 36.89 & 92.6 \\
\hline
\end{tabular}

A high association was observed between the growth variables (height and diameter) and the biomass amounts (total and compartments). Silveira (2009) also observed that DBH and height are strongly correlated with biomass, and reported that using the diameter variable in its pure or combined form is essential for models that seek to estimate biomass or carbon. When estimating biomass and carbon in native Atlantic Forest species using different models, Lacerda et al. (2009) concluded that the models that use the independent $\mathrm{DBH}$ variable in its pure form present a better fit.
The high correlation of biomass with $\mathrm{DBH}$ is important since the latter variable (DBH) is an easily measured characteristic, making it possible to estimate the dependent variables quickly and efficiently.

\subsection{Adjusting traditional allometric models}

The results of traditional adjustments using linear and non-linear models are presented in Table 4. It should be pointed out that the models for estimating total biomass and trunk biomass as a function of the $\mathrm{DBH}$, 
height and density variables provide more precise adjustments. The coefficient of determination adjusted for total biomass models ranged from 0.17 to 0.94 , while the standard error of the estimate varied between $16.29 \%$ and $48.44 \%$, which shows great variation for these statistics.

The model with the best performance for estimating total individual biomass was model 9, which had the best adjustment indicators $\left(\mathrm{R}_{\text {adj }}^{2}=0.91 ; \mathrm{S}_{\mathrm{yx}}=16.29 \%\right.$; $\mathrm{AIC}=60.67)$ and balanced graphical residual distribution (Figure 1). Model 6 also had high adjusted coefficient of determination, despite presenting a higher standard error of estimation and AIC value, in addition to a less uniform graphical residual distribution when compared to model 9. For the estimation of the trunk biomass, the model with the best fit was also model 9, with better results for the statistical indicators $\left(\mathrm{R}_{\text {adj }}^{2}=0.91 ; \mathrm{S}_{\mathrm{yx}}=16.24 \% ; \mathrm{AIC}=50.88\right)$ and a more balanced residual distribution (Figure 1).

Equations for the biomass estimation of needles/ leaves and branches presented less satisfactory performance when compared to total biomass and trunk equations. Similar to the present study, Behling et al. (2012) found lower adjustments of the equations for biomass estimates of canopy compartments in relation to those used for biomass estimates of the trunk and total biomass in a settlement of Acacia mearnsii at seven-years of age.

For the branch compartment, the best fit was obtained for the logistic model $\left(\mathrm{R}_{\text {adj }}^{2}=0.67 ; \mathrm{S}_{\mathrm{yx}}=32.06 \%\right.$; $\mathrm{AIC}=11.29)$. The linear model with the best fit was $\operatorname{model} 2\left(\mathrm{R}_{\text {adj }}^{2}=0.62 ; \mathrm{S}_{\mathrm{yx}}=34.12 ; \mathrm{AIC}=13.00\right)$. Models 1 and 3 presented precision statistics similar to those for model 2, however the latter presented better results and better graphical residual distribution (Figure 1).

Model 6 had the best fit $\left(\mathrm{R}^{2}\right.$ adj $=0.54 ; \mathrm{S}_{\mathrm{yx}}=39.92 \%$; AIC $=-2.95)$ in terms of the estimation of needle/leaf biomass, with a better graphical residual distribution (Figure 1). In all cases, the variance between the errors was constant for different observations, diagnosing data homoscedasticity, and the residual distribution was independent; meaning that the residues are not correlated in series, guaranteeing accuracy of the estimates. On the other hand, the results for the normality test showed that the residues presented normal distribution only for total aboveground biomass and for the branch and needle compartment biomasses, with the trunk biomass presenting non-normal distribution. Normality of the residues is essential so that the results of adjusting the linear regression model are reliable; therefore, the use of the model to predict the trunk biomass should be applied with caution. All tested models had a significant F value indicating a relationship between the variables. In a study with models similar to those used in the present study, Schikowski et al. (2013), when analyzing the biomass of Pinus spp. also found good results in the adjustments for total and trunk biomass, with high $\mathrm{R}_{\text {adj }}^{2}$ values and low $\mathrm{S}_{\mathrm{yx}}$ values

Incompatibility between total biomass and tree compartment estimates was observed when the equations were estimated independently. In other words, there was an inconsistency in the overall estimation of tree biomass, since the sum of the estimated values for biomass by compartment was not equal to the result of the equation for total tree biomass, indicating a need to apply simultaneous adjustments to ensure additivity of the estimates.

The result for simultaneous adjustment is shown in Table 5. We can see that the SUR method does not aim to improve performance of the equations, but rather to reconcile the biomass estimates by compartment and for total biomass. We also found that the residual distribution showed the same tendency when the two estimation methods were compared. Simultaneous adjustment maintained the homogeneity of variance of the data and also ensured independence of the residues. Furthermore, according to Behling et al. (2012), simultaneous adjustment has an advantage in the estimation process since it does not present distortions between the sum of the biomass obtained from the equations of each compartment and the total equation, as is the case in the independent adjustment.

When studying Pinus pinaster stands in central Portugal, Viana et al. (2013) found good-quality simultaneous predictive adjustment statistics for total aboveground biomass. Correia et al. (2008) found that standard errors generally decreased with simultaneous adjustment, leading to greater quality of the final models when estimating the total biomass and aboveground compartments of Pinus pinea located in southern Portugal. Simultaneous equations for biomass prediction were also developed for the Quercus suber and Quercus ilex species (Paulo \& Tomé, 2006). 

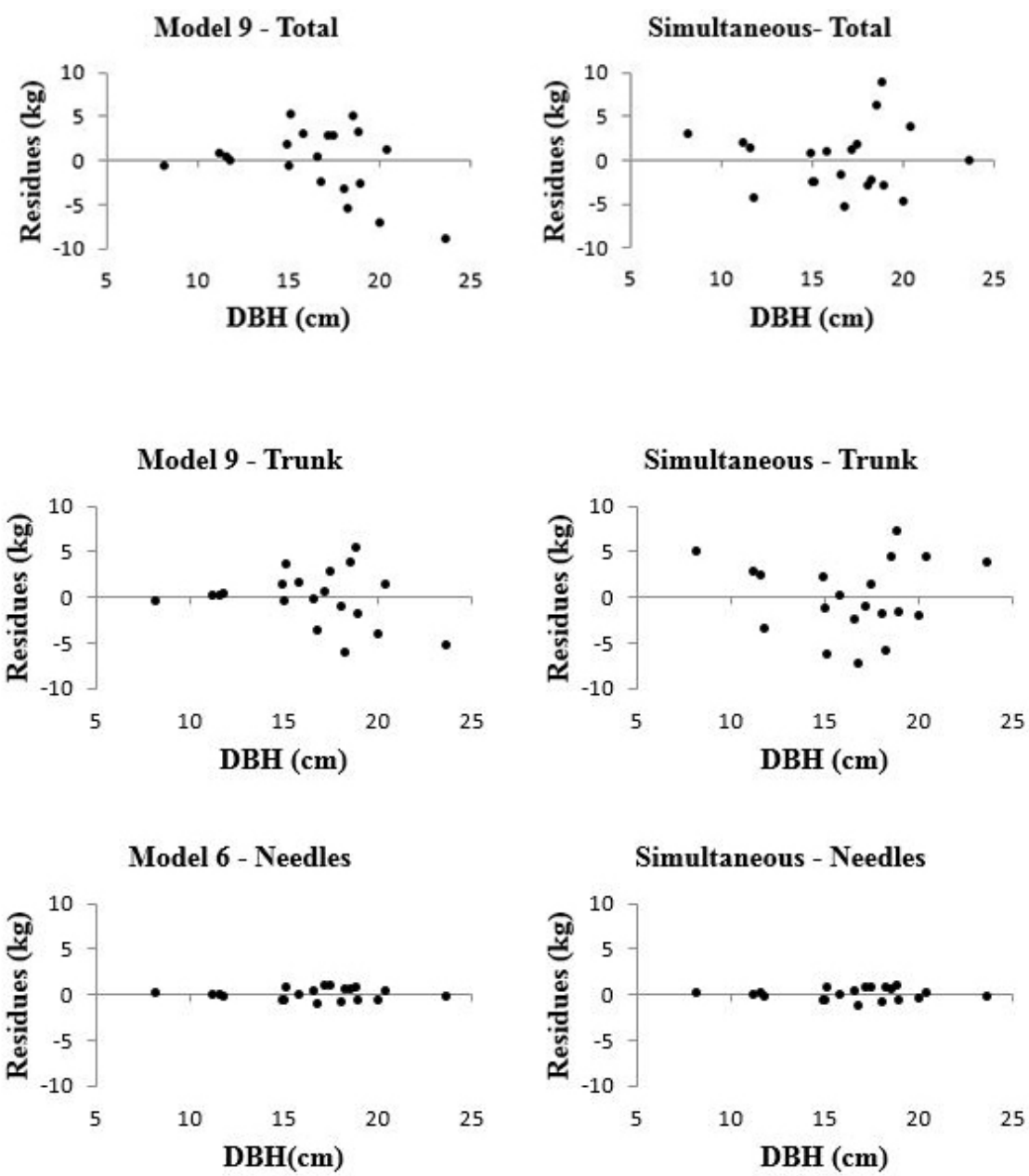

Logistic Model- Branches
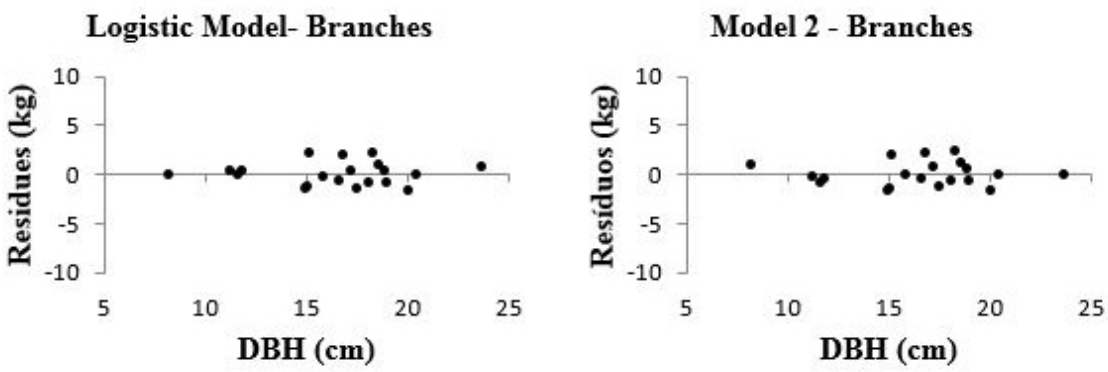

Simultaneous - Branches

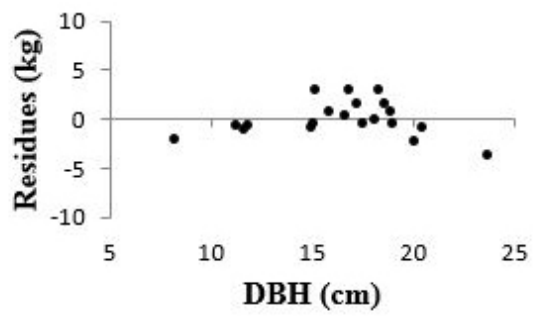

Figure 1. Absolute residual distribution resulting from the model adjustments for compartments. 
Table 5. Results of simultaneous equation adjustments for predicting biomass of Pinus caribaea compartments.

\begin{tabular}{|c|c|c|c|c|c|c|c|}
\hline Compartment & Simultaneous model & $\beta_{0}$ & $\beta_{1}$ & $\beta_{2}$ & $\beta_{3}$ & $\mathbf{R}_{\text {adj }}^{2}$ & $\mathrm{~S}_{\mathrm{yx}} \%$ \\
\hline Needles & bsneedles $=\beta_{0}+\beta_{1} \mathrm{DBH}+\beta_{2} \mathrm{TH}$ & -1.943 & 0.160 & 0.087 & & 0.53 & 40.34 \\
\hline Branches & bsbranches $=\beta_{0}+\beta_{1} \mathrm{DBH}+\beta_{2} \mathrm{DBH}^{2}$ & 8.631 & -1.213 & 0.054 & & 0.23 & 48.66 \\
\hline Trunk & bstrunk $=\beta_{0}+\beta_{1} \mathrm{DBH}+\beta_{2} \mathrm{ht}+\beta_{3} \rho$ & -41.5 & 1.760 & 1.374 & 39.377 & 0.84 & 21.80 \\
\hline Total & bstotal = bsneedles+bsbranches+bstrunk & & & & & 0.86 & 19.93 \\
\hline
\end{tabular}

Where: bstrunk = dry biomass of the trunk with bark; bsbranches = dry biomass of the branches; bsneedles = dry biomass of the needles; bstotal $=$ total dry biomass.

\section{CONCLUSION}

The trunk was the compartment with the highest contribution to total individual biomass, representing on average $77.88 \%$ of total individual tree biomass.

Total individual biomass and trunk, branch and needle compartment biomass values were more strongly correlated with DBH. A strong relationship between total aboveground biomass and the trunk and branch compartment biomass was observed, which is due to their cumulative character.

Models 9 and 6 showed the best performance for predicting total dry biomass, and for trunk and needle biomasses, respectively. The best results for predicting branch biomass were obtained with linear model 2 and the logistic model.

Applying the SUR method guarantees the additivity properties between biomass compartments and total biomass, avoiding distortions between the sum of the individual equations for each compartment and the total equation, which occurs when independent equations are used. Therefore, the simultaneous biomass adjustment allows for obtaining compatible estimates, providing better references for the integrated management of these variables.

\section{SUBMISSION STATUS}

Received: 19 june, 2017

Accepted: 1 aug., 2017

\section{CORRESPONDENCE TO}

\section{Vinícius Morais Coutinho}

Departamento de Ciências Florestais, Universidade Federal do Paraná - UFPR, Avenida Prefeito Lothário Meissner, 900, CEP 80060-000, Curitiba, PR, Brasil e-mail: viniciusmorais@ufpr.br

\section{REFERENCES}

Alvares CA, Stape JL, Sentelhas PC, Moraes Gonçalves JL, Sparovek G. Köppen's climate classification map for Brazil. Meteorologische Zeitschrift 2013; 22(6): 711-728. http://dx.doi.org/10.1127/0941-2948/2013/0507.

Azevedo GB, Sousa GTO, Barreto PAB, Conceição V Jr. Estimativas volumétricas em povoamentos de eucalipto sob regime de alto fuste e talhadia no sudoeste da Bahia. Pesquisa Florestal Brasileira 2011;31(68): 309-318. http:// dx.doi.org/10.4336/2011.pfb.31.68.309.

Balbinot R, Valério AF, Sanquetta CR, Caldeira MVW, Silvestre R. Estoque de carbono em plantações de Pinus spp. em diferentes idades no sul do estado do Paraná. Revista Floresta 2007; 36(2): 317-324.

Behling A, Sanquetta CR, Corte APD, Simon AA, Nunes GS. Equações simultâneas para estimativa da biomassa em plantios comerciais de Acácia-Negra. Enciclopédia Biosfera 2012; 8(15): 853-860.

Correia A, Faias S, Tomé M, Evangelista M, Freire J, de Carvalho PO. Ajustamento simultâneo de equações de biomassa de pinheiro manso no sul de Portugal. Silva Lusitana 2008; 16(2): 197-205.

Cunia $\mathrm{T}$. On tree biomass tables and regression: some statistical comments. In: Frayern WE, editor. Forest resource inventory workshop proceedings. Colorado: Colorado State University; 1979.

Dong L, Zhang L, Li F. A compatible system of biomass equations for three conifer species in Northeast, China. Forest Ecology and Management 2014; 329: 306-317. http:// dx.doi.org/10.1016/j.foreco.2014.05.050.

Giongo M, Silva DB, Koehler HS, Marchetti M. Inventário de biomassa em um plantio de Pinus elliottii engelm, aos 23 anos de idade. Journal of Biotechnology and Biodiversity 2011; 2(3): 81-86.

Jacobs MW, Cunia T. Use of dummy variables to harmonize tree biomass tables. Canadian Journal of Forest Research 1980; 10(4): 483-490. http://dx.doi.org/10.1139/x80-079.

Kozak A. Methods of ensuring additivity of biomass components by regression analysis. Forestry Chronicle 1970; 46(5): 402-404. http://dx.doi.org/10.5558/tfc46402-5.

Lacerda JD, Couto HD, Hirota MM, Pasishnyk N, Polizel JL. Estimativa da biomassa e carbono em áreas restauradas 
com plantio de essências nativas. Emendabis Mensvram Silvarvm 2009; 5: 1-23.

Laird AK. Dynamics of relative growth. Growth 1965; 29(3): 249-263. PMid:5865687.

Lima MCD, Barreto-Garcia PAB, Sanquetta CR, Novaes AB, Melo LC. Estoques de biomassa e carbono de Pinus caribaea var. hondurensis em plantio homogêneo no Sudeste da Bahia. Ciência Rural 2016; 46(6): 957-962.

Melo LC, Barreto PAB, Oliveira FGRB, Novaes AB. Estimativas volumétricas em povoamento de Pinus caribaea var, hondurensis no sudoeste da Bahia. Pesquisa Florestal Brasileira 2013; 33(76): 379-386.

Nelder JA. The fitting of a generalization of the logistic curve. Biometrics 1961; 17(1): 89-110. http://dx.doi. org/10.2307/2527498.

Parresol BR. Assessing Tree and stand biomass: a review with examples and critical comparisons. Forest Science 1999; 45(4): 573-593.

Parresol BR. Additivity of nonlinear biomass equations. Canadian Journal of Forest Research 2001; 31(5): 865-878. http://dx.doi.org/10.1139/x00-202.

Paulo JA, Tomé M. Equações para estimação do volume e biomassa de duas espécies de carvalhos: Quercus suber e Quercus ilex. Lisboa: Universidade Técnica de Lisboa; 2006.

Pelissari AL, Lanssanova LR, Drescher R. Modelos volumétricos para pinus tropicais, em povoamento homogêneo, no Estado de Rondônia. Pesquisa Florestal Brasileira 2011; 31(67): 173-181.

Rezende D. Seqüestro de carbono: uma experiência concreta. Goiânia: Terra; 2000.

Richards JF. A flexible growth function for empirical use. Journal of Experimental Botany 1959; 10(2): 290-301. http://dx.doi.org/10.1093/jxb/10.2.290.
Sanquetta CR, Behling A, Corte APD, Péllico Netto S, Schikowski AB, Amaral MK. Simultaneous estimation as alternative to independent modeling of tree biomass. Annals of Forest Science 2015; 72(8): 1099-1112. http:// dx.doi.org/10.1007/s13595-015-0497-2.

Sanquetta CR, Corte APD, Maas GCB. The role of forests in climate change. Quebracho 2011; 19(1-2): 84-96.

Schikowski AB, Corte APD, Sanquetta CR. Modelagem do crescimento e de biomassa individual de Pinus. Pesquisa Florestal Brasileira 2013; 33(75): 269-278. http://dx.doi. org/10.4336/2013.pfb.33.75.503.

Schumacher FX. A new growth curve and its application to timber yield studies. Journal of Forestry 1939; 37: 819-820.

Silva JAA. Dynamics of stand structure in fertilized slash pine plantations. Athens: University of Georgia; 1986.

Silveira P. Ajuste de modelos matemáticos para estimar biomassa aérea em floresta ombrófila densa. Revista Floresta 2009; 39(4): 743-752.

Soares CPB, Silva GF, Martins SB. Influence of section lenghts on volume determination in Eucalyptus trees. Cerne 2010; 16(2): 155-162. http://dx.doi.org/10.1590/ S0104-77602010000200006.

Viana H, Marques CP, Fonseca T. Predição da biomassa aérea da pinus pinaster Aiton por um sistema de equações aditivas integrado no simulador Open Source modis pinaster. Silva Lusitana, 2013; 21(N. esp.):77-86

Watzlawick LF. Teores de carbono em espécies da Floresta Ombrófila Mista. In: Sanquetta CR, editor. Fixação de carbono: atualidades, projetos e pesquisas. Curitiba: UFPR; 2004.

Weibull WA. A statistical distribution function of wide applicability. Journal of Applied Mechanics 1951; 18(1): 293-297. 